\title{
On the existence of a new phase in SASD
}

\author{
I.E.Lipinski ${ }^{1}$, J.Kuriata ${ }^{1}$, N.A.Korynevskii ${ }^{2,3}$ \\ 1 Institute of Physics, Technical University of Szczecin, \\ 17 Aleja Piastow, 71-310 Szczecin, Poland \\ 2 Institute for Condensed Matter Physics \\ of the National Academy of Sciences of Ukraine, \\ 1 Svientsitskii Str., 79011 Lviv, Ukraine \\ 3 Institute of Physics, University of Szczecin, \\ 15 Wielkopolska Str., 70-451 Szczecin, Poland
}

Received September 13, 2002

\begin{abstract}
Neutron irradiation induced paramagnetic centers are investigated using EPR. It is shown that the observed EPR signal appears to be mainly due to a variety of radicals. Temperature dependence of the EPR linewidth is attempted to be correlated both with the results supplied by inelastic neutron scattering spectra and by the recently developed theoretical model for phase transitions in sodium ammonium sulphate dihydrate type crystals.
\end{abstract}

Key words: sodium ammonium sulphate dihydrate, electron paramagnetic resonance, phase transitions

PACS: $76.30 . K, 77.80 . B h$

\section{Introduction}

Sodium ammonium sulphate dihydrate (SASD) and sodium ammonium selenate dihydrate (SASeD) are orthorhombic with space group $\mathrm{P} 2{ }_{1}$ and four molecules in the unit cell in the paraelectric phase [1] and $\mathrm{P} 2_{1} 2_{1} 2_{1}$ in the ferroelectric phase [2]. The crystal structure of SASD may be considered to consist of $\mathrm{NaO}_{6}$ octahedra, sharing three $\mathrm{O}$ atoms on a face, aligned along [100], interlaced with chains of $\left(\mathrm{NH}_{4}^{+}\right)-\left(\mathrm{SO}_{4}^{2-}\right)-\left(\mathrm{NH}_{4}^{+}\right)$with the two types of chain being linked by sharing one $\mathrm{O}$ in the $\mathrm{SO}_{4}$ tetrahedra and hydrogen bonds.

The crystal undergoes the first-order transition from para- to ferroelectric phase at $101 \mathrm{~K}$.

Many experimental methods have been used in order to derive some information about the nature of phase transitions taking place in SASD type crystals. The spectroscopic methods used so far seem to be most effective. In this context, it is 
worthwhile mentioning two electron paramagnetic resonance (EPR) studies of radiation induced paramagnetic centers. The first one is reported in [3] and deals with $\gamma$-irradiated SASeD powder and single crystals. The induced centers were identified as being due to $\mathrm{SeO}_{2}^{-}$and $\mathrm{SeO}_{3}^{-}$and $\mathrm{SeO}_{4}^{-}$radicals. The phase transition presented itself by a small change in the structure and the components of both the $g$ - and the A-tensors. The second one, is reported in [4] and describes the behaviour of $\mathrm{X}$-irradiation induced centers in SASD. The observed EPR spectrum was very complex because it proved to be due to the contribution of at least eight different type centers. Probably the complexity of the EPR spectrum hindered the possibility of a closer inspection of the effect of the phase transition on the spectrum.

This paper describes our new results obtained for neutron-irradiation induced centers in SASD.

\section{Experimental}

The powdered samples of SASD used for EPR measurements were taken from the bulk sample used previously in neutron scattering studies carried out using the NERA inverted geometry time-of-flight spectrometer with the neutron source being the IBR-2 high-flux pulsed reactor working at the JINR in Dubna. The bulk sample was subjected to neutron irradiation for four days. The EPR studies were accomplished one month later because straight after the irradiation the sample was highly radioactive. EPR measurements were carried out using a standard X-band spectrometer operating with $100 \mathrm{kHz}$ modulation of the steady magnetic field. The spectra were observed in the temperature range from $300 \mathrm{~K}$ to $30 \mathrm{~K}$.

\section{Results and discussion}

As mentioned above, prior to EPR measurements, neutron diffraction and inelastic neutron scattering spectra had been measured. The results of this experiment are described in [5]. The temperature neutron diffraction spectrum could be fitted with the known X-ray diffraction studies [1], supporting the X-ray diffraction dilatometry measurements of Osaka [6], and exhibited a sudden change below $T_{\mathrm{c}}=101 \mathrm{~K}$. Thus, these spectra clearly showed that the material we used in the neutron experiment was correctly chosen.

Much more interesting results were obtained for the inelastic neutron scattering spectra shown in figure 1 in the form of the generalized phonon density of states $G(\omega)$.

A particular behaviour of the system under discussion was found for $\omega<50 \mathrm{~cm}^{-1}$ (i.e. the region at which the crystal dynamics plays the dominant role). Below $110 \mathrm{~K}$ and above $160 \mathrm{~K}$ the generalized phonon density of states is proportional to $\omega^{2}$. This means, as is well known, that here we deal with the dynamics represented by the ordered crystal. However, in the temperature range from about $160 \mathrm{~K}$ to $110 \mathrm{~K}$ the $G(\omega)$ is linear in $\omega$. 


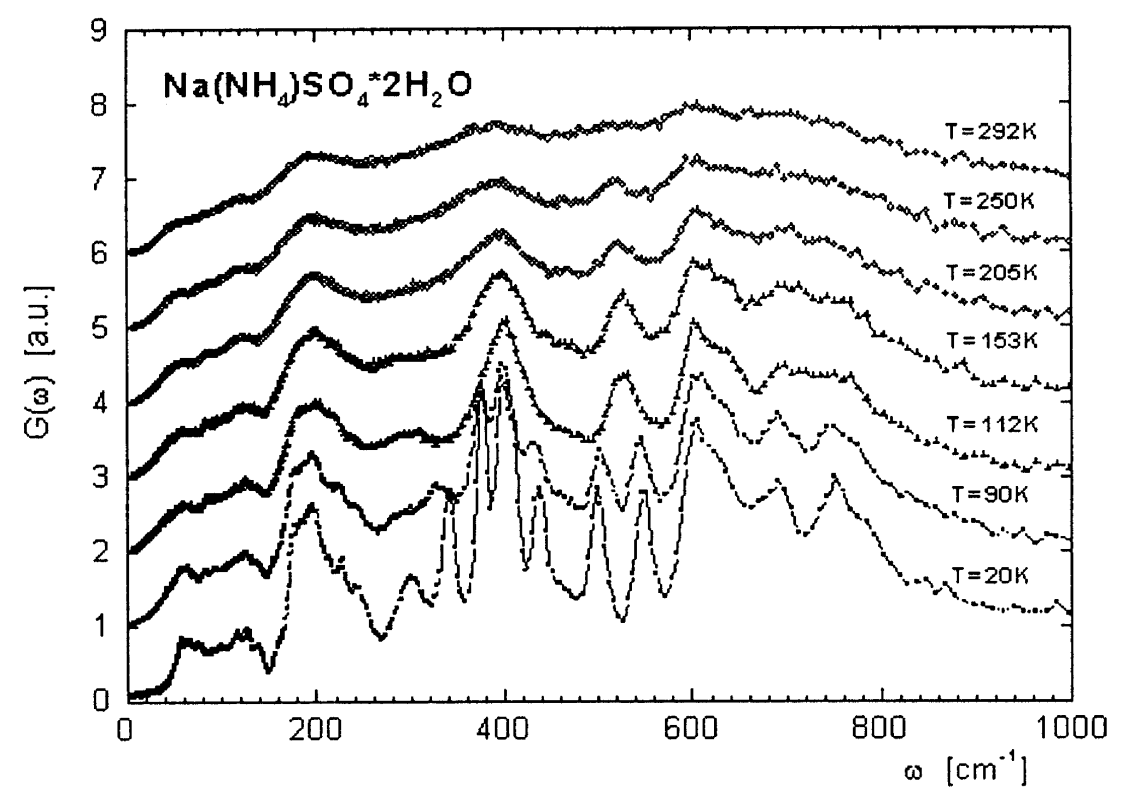

Figure 1. Temperature dependence of the generalized phonon density of states.

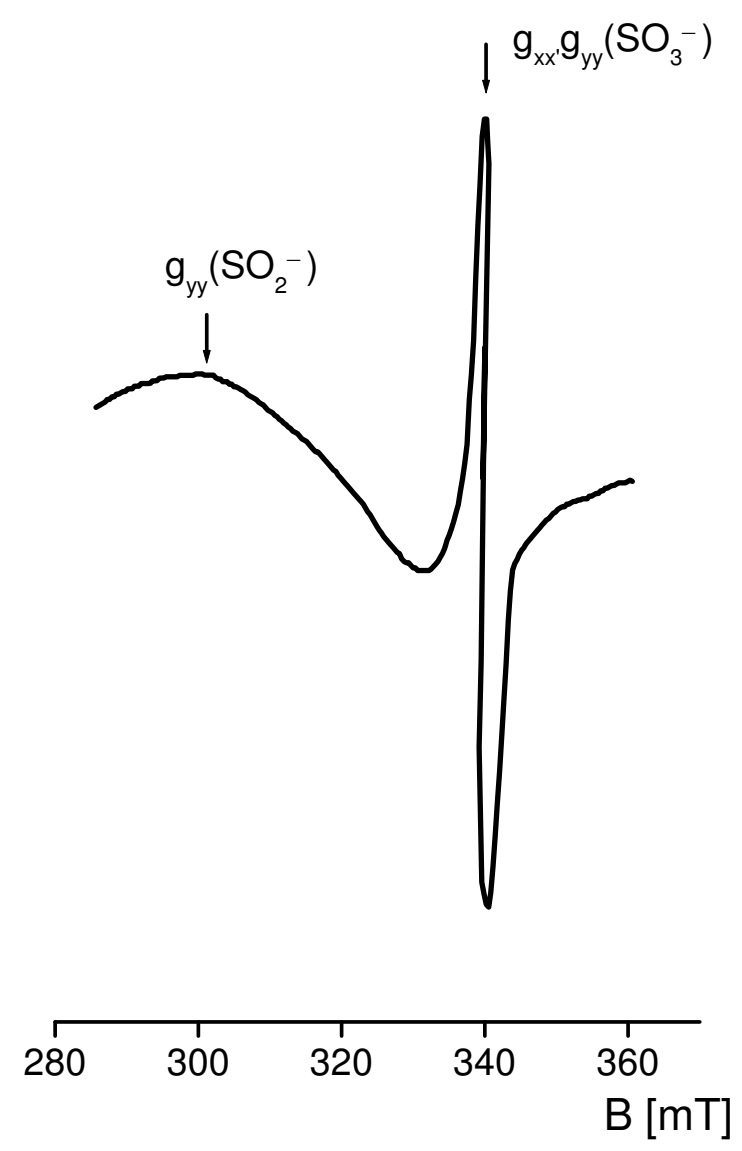

Figure 2. EPR spectrum of neutron induced paramagnetic centers in SASD.
Two physically different interpretations may be given to account for such a behaviour: either in this temperature range the system has a character of the orientational proton glass, or one detects a precursor signal of the incipient instability connected with a soft optic mode responsible for the ferroelectric phase transition.

In order to obtain some additional information, EPR measurements were carried out on the samples taken from the bulk material used for neutron studies. They proved that the observed EPR spectrum (see figure 2) is relatively simple (compared to those obtained by Xray irradiation) and is very similar to those described in [3]. Following the identification procedure given in [3] we ascribe this spectrum to $\mathrm{SO}_{n}^{-}$type radicals (with $n=2,3,4$ ).

It is worth noting here that the results of the measurements reported in [3] were taken only in two temperature points: at $300 \mathrm{~K}$ (i.e. above $T_{\mathrm{c}}$ ) and at $77 \mathrm{~K}$ (i.e. below $T_{\mathrm{c}}$ ). 


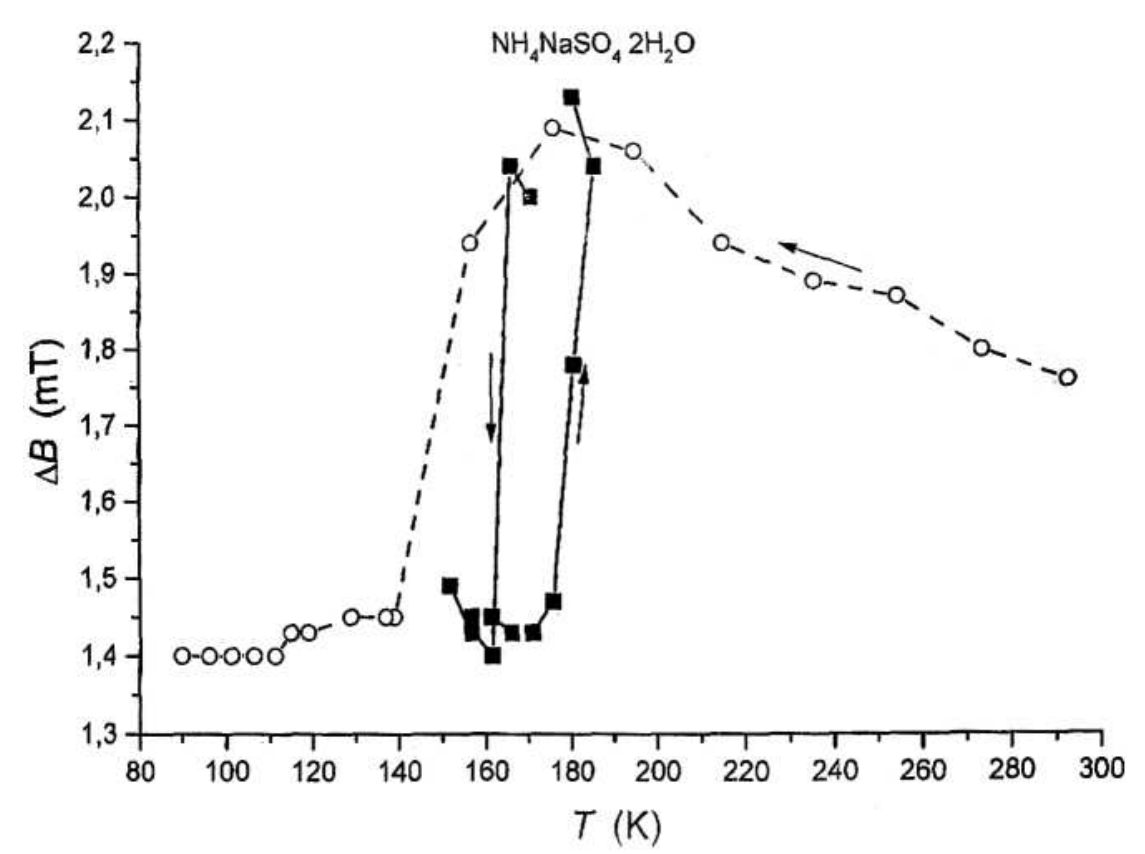

Figure 3. The temperature dependence of the EPR linewidth for SASD measured for neutron irradiation induced paramagnetic centers.

However, the data obtained there indicated for the distortion of the $\mathrm{SO}_{4}^{-}$radical. This radical undergoes rapid reorientations at room temperature. As the temperature is reduced the $g$-tensor begins to show rhombic symmetry because of the slowing down of the $\mathrm{SO}_{4}^{-}$reorientations near $T_{\mathrm{c}}$ leading to the appearance of a new structure involving hydrogen bonds.

We have measured the temperature dependence of the neutron induced paramagnetic centers in the temperature range from 300 to $90 \mathrm{~K}$. Like in [3], we found that below $T_{\mathrm{c}}$ one observes a small change in the components of the $g$-tensor for both radicals. However, the temperature dependence of the EPR linewidth of the narrow line (see figure 2) shows a particular behaviour in the temperature range from 190 to $140 \mathrm{~K}$. In this temperature range the EPR linewidth changes essentially, what approximately reproduces the behaviour of the generalized phonon density of states.

Furthermore, we have seen quite significant hysteresis shown in figure 3. On the basis of this observation we incline to accept that indeed a new phase appears in the system before it undergoes a phase transition.

Based on experimental data obtained mainly from EPR studies, a new theoretical model for the nature of the phase transitions taking place in SASD type crystals has been suggested [7-8]. The model takes into account that $\mathrm{SO}_{4}\left(\mathrm{SeO}_{4}\right)$ groups contribute predominantly to the phase transitions occurring in these crystals. The modified Mitsui-type model, which includes both long- and short-range correlations has been used. The Mitsui Hamiltonian, formulated in the cluster form and applied to two-sublattice case showed that for the system under discussion one can distinguish two order parameters: the usual polarization $P$ and a new one $\xi$. This latter parameter reflects an antiferroelectric type coupling taking place in each particular 


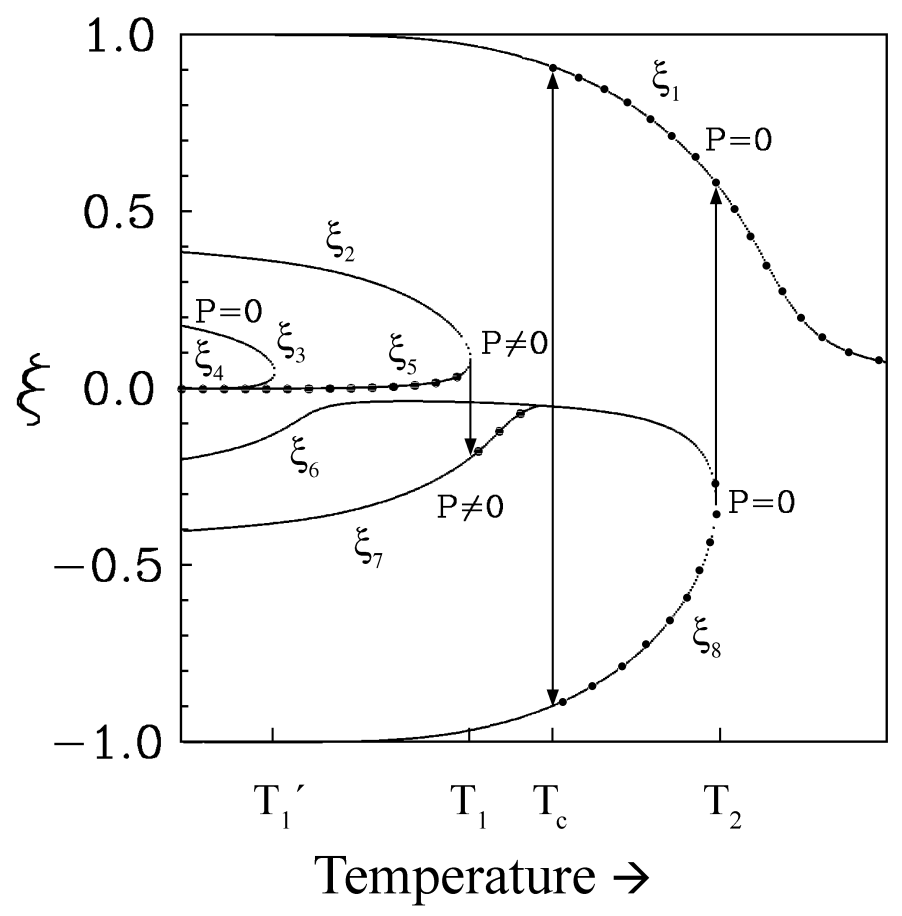

Figure 4. Temperature dependence of eight $\xi$-branches. The curves indicated by dotted points correspond to real solutions for $\xi$ ensuring the minimum of free energy. The arrows show temperature points at which the system undergoes transitions from one branch to another.

cell. The temperature dependence of these parameters was obtained minimizing the free energy with respect to the $P$ and $\xi$ parameters. In the context of this paper, the temperature dependence of $\xi$ parameter is of particular interest. This dependence is shown in figure 4 . Generally, in the whole temperature range there are eight branches of $\xi$. It is interesting to note that the particular behaviour of $\xi$ is observed in the temperature range $T_{\mathrm{c}}<T<T_{2}$. This temperature range correlates quite well with the EPR data on the temperature dependence of the linewidth. We do not yet exactly know how both the experimental and the theoretical facts described above can be reasonably linked. However, the anomalies detected by neutron and EPR studies as well as theoretical considerations seem to indicate that some new phase of the material under discussion exists in the region from $T_{\mathrm{c}}$ to $T=200 \mathrm{~K}$.

\section{References}

1. Corrazzo E., Sabelli C., Guiseppetti G. // Acta Crystallogr., 1967, vol. 22, p. 683.

2. Aleksandrov K.S., Aleksandrova I.P., Shabanov V.F., Yuzvak V.I., Nozik Y.Z., Fikin L.I. // Phys. Status Solidi (a), 1978, vol. 45, p. 53.

3. Ramani K., Srinivasan R. // Mol. Phys., 1981, vol. 44, p. 125.

4. Baker J.M., Cook M.I., Tronconi A.L., Kuriata J., Sadlowski L. // J. Phys.: Condens. Matter, 1993, vol. 5, p. 459. 
5. Lipinski I.E., Kuriata J., Natkaniec I., Pawlukojc A. // Phys. Status Solidi (b), 2001, vol. 227 , p. 477.

6. Osaka T. // J. Phys. Soc. Japan, 1978, vol. 45, p. 571.

7. Kuriata J., Lipinski I.E., Korynevskii N.A., Bodziony T. // Physica B, 2001, vol. 307, p. 203.

8. Lipinski I.E., Korynevskii N.A., Kuriata J., Pastusiak W. // Physica B, 2003, vol. 327, p. 116.

\title{
Про існування нової фази в SASD
}

\author{
I.Е.Ліпіньскі ${ }^{1}$, Є.Куріата ${ }^{1}$, М.А.Кориневський ${ }^{2,3}$ \\ 1 Інститут фізики, Політехніка Щецінська, \\ Польща, 71-310 Щецін, Алея Піастув, 17 \\ 2 Інститут фізики конденсованих систем НАН України, \\ 79011 Львів, вул. Свєнціцького, 1 \\ 3 Інститут фізики, Щецінський університет, \\ Польща, 70-451 щецін, вул. Вєлькопольська, 15
}

Отримано 13 вересня 2002 p.

Парамагнітні центри, індуковані завдяки опроміненню нейтронами кристалу SASD, досліджуються методом EПР. Доведено, що спостережуваний ЕПР-сигнал походить від різноманітного типу радикалів $\mathrm{SO}_{n}^{-}$. Встановлено кореляцію між температурнозалежною шириною лінії цього сигналу і спектром непружного розсіяння нейтронів, а також із нещодавно запропонованою теоретичною моделлю фазових переходів у сполуках типу амонієво-натрієвого дигідрату сірки.

Ключові слова: амонієво-натрієвий дигідрат сірки, електронний парамагнітний резонанс, фазові переходи

PACS: $76.30 . K, 77.80 . B h$ 